in vivo $33: 425-432(2019)$

doi:10.21873/invivo.11490

\title{
Fusigen Reduces Intracellular Reactive Oxygen Species and Nitric Oxide Levels
}

\author{
VORAWAT KITIYANANT ${ }^{1}$, PONGTHARIN LOTRAKUL ${ }^{2}$, CHOMPOONIK KANCHANABANCA $^{3}$, \\ PANUWAT PADUNGROS ${ }^{4}$, HUNSA PUNNAPAYAK $^{5}$, SEHANAT PRASONGSUK $^{2}$ and PITHI CHANVORACHOTE ${ }^{6,7}$ \\ ${ }^{1}$ Program in Biotechnology, Faculty of Science, Chulalongkorn University, Bangkok, Thailand; \\ ${ }^{2}$ Plant Biomass Utilization Research Unit, Department of Botany, \\ Faculty of Science, Chulalongkorn University, Bangkok, Thailand; \\ ${ }^{3}$ Department of Microbiology, Faculty of Science, Chulalongkorn University, Bangkok, Thailand; \\ ${ }^{4}$ Department of Chemistry, Faculty of Science, Chulalongkorn University, Bangkok, Thailand \\ ${ }^{5}$ Department of Biology, Faculty of Science and Technology, Universitas Airlangga, Surabaya, Indonesia; \\ ${ }^{6}$ Department of Pharmacology and Physiology, Faculty of Pharmaceutical Sciences, \\ Chulalongkorn University, Bangkok, Thailand; \\ ${ }^{7}$ Cell-based Drug and Health Product Development Research Unit, Chulalongkorn University, Bangkok, Thailand
}

\begin{abstract}
Background/Aim: Oxidative stress caused by the production of excessive cellular reactive oxygen species (ROS) and high levels of nitric oxide contribute to several human pathologies. This study aimed to examine the anti-oxidant effects of fusigen, a compound produced from Aureobasidium melanogenum. Materials and Methods: Extracts of A. melanogenum were selected as a source for the isolation of fusigen. The anti-oxidant, nitric oxide suppression, as well as the free radical scavenging activities of fusigen were tested in BEAS-2B human bronchial epithelial cell line (BEAS-2B cells) and human dermal papilla cells (DP cells) using specific fluorescence dyes and flow cytometry analysis. Cell viability was determined by the MTT assay. Results: Fusigen did not exert cytotoxicity in the human normal BEAS-2B and DP cells at concentrations up to $100 \mu \mathrm{M}$. Fusigen decreased basal levels of cellular ROS, as well as the levels of ROS induced by hydrogen peroxide and ferrous ion enrichment. ROS decreasing
\end{abstract}

This article is freely accessible online.

Correspondence to: Pithi Chanvorachote, Ph.D., Department of Pharmacology and Physiology, Faculty of Pharmaceutical Sciences, and Cell-based Drug and Health Product Development Research Unit, Chulalongkorn University, Bangkok, Thailand. Tel: +662 2188285, Fax: +662 2188340, e-mail: pithi_chan@yahoo.com; Sehanat Prasongsuk, Ph.D., Department of Botany, Faculty of Science, and Plant Biomass Utilization Research Unit, Chulalongkorn University, Bangkok, Thailand. Tel: +66 22185493, e-mail: sehanat.p@chula.ac.th

Key Words: Siderophore, fusigen, A. melanogenum, reactive oxygen species, nitric oxide. effect was confirmed in DP cells. In addition, fusigen treatment suppressed intracellular NO levels in both BEAS-2B and DP cells. Conclusion: The optimal process of production of purified fusigen from A. melanogenum was determined. Fusigen exhibited a low cytotoxic effect and the potential to suppress ROS and NO. These results demonstrated that fusigen may be used for the treatment or prevention of human diseases.

Reactive oxygen species (ROS) are the reactive derivatives of oxygen with or without radicals, such as hydrogen peroxide $\left(\mathrm{H}_{2} \mathrm{O}_{2}\right)$, hydroxyl radical $\left({ }^{\circ} \mathrm{OH}\right)$, and superoxide radical $\left(\mathrm{O}_{2}{ }^{-}\right)$. These harmful ROS could be produced everywhere in our body and in all cells, and exert cytotoxicity by attacking necessary biomolecules including DNA, RNA, proteins and lipids (1). Normally, cells manage ROS through the production of antioxidants. However, the excess ROS could cause oxidative stress in cells, leading to cell death or disease (2). Hence, providing antioxidants to cells could be another way to control ROS.

Iron (II) or ferrous $\left(\mathrm{Fe}^{2+}\right)$ has single electron transfer competency that can cause many radical reactions (3). Furthermore, the excessive free iron mediates the production of highly reactive radicals, namely hydroxyl radicals, through the Fenton reaction $(4,5)$. The direct DNA damage caused by the interaction between hydroxyl radicals and DNA is well known to cause cell and tissue damage (6) leading to several human diseases. Therefore, iron chelators might be one of the solutions or key substances to control cellular hydroxyl radicals. Nitric oxide (NO) is a cellular mediator that has been involved in physiology and pathology. As NO is produced by the immune cells in order to destroy invading microorganisms, it may also be toxic to the neighboring cells and tissues (7). 
In addition, $\mathrm{NO}$ can directly interact with free radicals to generate highly toxic molecules (8). Thus, researchers have reported on the promising role of NO inhibitor and NO scavengers in protecting against certain forms of tissue injury and inflammation (9-12).

Siderophores are natural small iron chelating ligands produced by many microorganisms including bacteria and fungi (13). Nowadays, more than 500 structures of siderophore have been reported in databases (14). Many siderophores have been studied regarding their medical applications, for instance, selective drug delivery, iron overload diseases treatment, haemochromatosis treatment, antimalaria activity, removal of trans element, as well as, free radical scavenging activity (15, 16). Hence, there is a possibility that siderophores act as antioxidants. Moreover, some hydroxamic siderophores can bind to nitric oxide (NO) and decrease mortality in a septic shock model. Aureobasidium melanogenum is a yeast-like fungus which can be found in diverse environments (17-21). This species can produce many valuable products, such as enzymes, polysaccharides and also siderophores (22). The siderophore production, structure, and antibacterial activity from their marine-derived A. melanogenum HN6.2 has been reported. This siderophore was identified as fusigen (Figure 1) (23). In this study, the antioxidant activity of fusigen, purified from extracts of A. melanogenum, as shown in Figure 2, was examined in cell systems.

\section{Materials and Methods}

Materials. The human bronchial epithelial BEAS-2B (BEAS) cells were obtained from the American Type Culture Collection (Rockville, MD, USA). Immortalized dermal papilla cells (DP cells) were obtained from Applied Biological Materials Inc. (Richmond, BC, Canada). $\mathrm{H}_{2} \mathrm{O}_{2}$ was purchased from Siribuncha (Bangkok, Thailand). Sucrose, $\left(\mathrm{NH}_{4}\right)_{2} \mathrm{SO}_{4}, \mathrm{~K}_{2} \mathrm{HPO}_{4}$, citric acid, $\mathrm{MgSO}_{4}, \mathrm{ZnSO}_{4}$, and $\mathrm{FeSO}_{4}$ were purchased from Ajax Finechem Pty Ltd (Australia). L-glutamate and L-arginine were purchased from Alfa Aesar (Lancashire, UK). Lorinithine was purchased from Merck (Darmstadt, Germany). Dulbecco's modified Eagle's medium (DMEM), fetal bovine serum (FBS), L-glutamine, penicillin, and streptomycin were purchased from Gibco (Waltham, MA, USA). Diaminofluorescein-FM diacetate (DAFFM DA) was purchased from Santa Cruz Biotechnology (Dallas, TX, USA). 2', 7'-Dichlorofluorescin diacetate (DCFH-DA), 3-(4,5Dimethylthiazol-2-yl)-2,5 diphenyltetrazolium bromide (MTT), and dimethyl sulfoxide (DMSO) were purchased from Sigma Chemical, Inc. (St. Louis, MO, USA).

Screening of siderophore production. A number of Aureobasidium melanogenum isolates from the Plant Biomass Utilization Research Unit (PBURU), Chulalongkorn University (Bangkok, Thailand) culture collection were screened for siderophore production. Each isolate of A. melanogenum was cultivated in iron depleted medium (2.5\% sucrose, $0.4 \%\left(\mathrm{NH}_{4}\right)_{2} \mathrm{SO}_{4}, 0.3 \% \mathrm{~K}_{2} \mathrm{HPO}_{4}, 0.1 \%$ citric acid, $0.008 \% \mathrm{MgSO}_{4}$, and $0.0002 \% \mathrm{ZnSO}_{4}$ ) at $25^{\circ} \mathrm{C}$, under continuous stirring at $200 \mathrm{rpm}$ for 5 days. Cultured medium was collected and cells were discarded by centrifugation. The siderophore concentration was measured using a ferric perchlorate assay and monitoring absorbance at $450 \mathrm{~nm}$.

Optimization of siderophore production. Various combinations of carbon and nitrogen sources were used into iron deplete media to determine the best carbon and nitrogen sources for siderophore production. Optimum concentration of the best carbon and nitrogen sources was investigated using a central composite design (CCD) and response surface methodology (RSM). Additional supplements such as amino acids were studied for enhancing the siderophore production.

Siderophore production and extraction. A loop full of $A$. melanogenum VK02 was inoculated into iron depleted medium at $25^{\circ} \mathrm{C}$, under continuous stirring at $200 \mathrm{rpm}$ for 2 days. The yeast cells $\left(5 \times 10^{7}\right.$ cells) were transferred to $100 \mathrm{ml}$ of siderophore production medium (7\% sucrose, $1.1 \%\left(\mathrm{NH}_{4}\right)_{2} \mathrm{SO}_{4}, 0.3 \% \mathrm{~K}_{2} \mathrm{HPO}_{4}, 0.1 \%$ citric acid, $0.008 \% \mathrm{MgSO}_{4}, 0.0002 \% \mathrm{ZnSO}_{4}$, and $1.5 \mathrm{mM} \mathrm{L}$-ornithine) and cultured for 5 days at $25^{\circ} \mathrm{C}$, and $200 \mathrm{rpm}$. The culture was centrifuged at $13,000 \mathrm{rpm}$ at $4^{\circ} \mathrm{C}$ for $20 \mathrm{~min}$. The supernatant was reduced 10 folds on a rotary evaporator at $40^{\circ} \mathrm{C}$. Three volumes of cold ethanol were added into the concentrated supernatant and vigorously shaken before allowing precipitation to occur in the freezer overnight. The mixture was filtrated to remove the precipitate following by solvent extraction according to the methods described by Neilands (13) and Wang (23) without $\mathrm{FeCl}_{3}$ supplementation.

Fusigen purification. Extracted crude siderophore was concentrated to several milliliters before being loaded onto a Zetadex LH-20 packed column $(3 \times 150 \mathrm{~cm})$. Water was used as a mobile phase. Siderophore in the fractions was detected using ferric perchlorate assay and pooled together before being concentrated to several milliliters. The $\mathrm{C}_{18}$ reverse phase packed column $(2 \times 70 \mathrm{~cm})$ was used in purification using a gradient of methanol: $\mathrm{H}_{2} \mathrm{O}(0-50 \%)$. The fractions contained siderophore were collected and their purity was analyzed by reverse phase high-performance liquid chromatography (HPLC) (Acclaim $120 \mathrm{C} 18,46 \times 150 \mathrm{~mm}, 5 \mu \mathrm{m}, 120 \AA$ ) using isocratic $20 \%$ methanol; flow rate $0.75 \mathrm{ml} / \mathrm{min}$; detect wavelength $201 \mathrm{~nm}$.

Cell culture. The BEAS cells and the DP cells were cultured in DMEM containing 10\% fetal bovine serum, 2 mM L-glutamine, 100 $\mathrm{U} / \mathrm{ml}$ penicillin, and $100 \mu \mathrm{g} / \mathrm{ml}$ streptomycin. Cell cultures were maintained under $5 \% \mathrm{CO}_{2}$ at $37^{\circ} \mathrm{C}$ in a humidified incubator.

Cytotoxicity assays. Cells were seeded onto 96-well plates at a density of $7.5 \times 10^{4}$ cells/well and incubated at $37^{\circ} \mathrm{C}$ overnight. After removal of medium, cells were treated with various concentrations of fusigen for $24 \mathrm{~h}$ at $37^{\circ} \mathrm{C}$ and cell viability was evaluated using the MTT assay. The intensity of the MTT product was then determined at $570 \mathrm{~nm}$ using Wallac 1420 VICTOR2 ${ }^{\text {TM }}$ microplate reader (PerkinElmer, Waltham, MA, USA). The relative percentage of cell viability was calculated by dividing the absorbance of treated cells by that of the control cells.

ROS detection. The accumulated intracellular ROS were assessed using the fluorescent probe DCFH-DA and flow cytometry. In brief, cells were trypsinized and washed before being resuspended and incubated with $10 \mu \mathrm{M}$ DCFH-DA and different concentrations of fusigen in serum free DMEM for $30 \mathrm{~min}$ at $4^{\circ} \mathrm{C}$. DCFH-DA incubated cells were treated with $100 \mu \mathrm{M} \mathrm{H}_{2} \mathrm{O}_{2}$ and $150 \mu \mathrm{M} \mathrm{FeSO}_{4}$ for $1 \mathrm{~h}$ at $37^{\circ} \mathrm{C}$. Cells were washed, resuspended and immediately measured for green fluorescence intensity by Guava ${ }^{\circledR}$ easyCyte flow cytometer (Merck, 


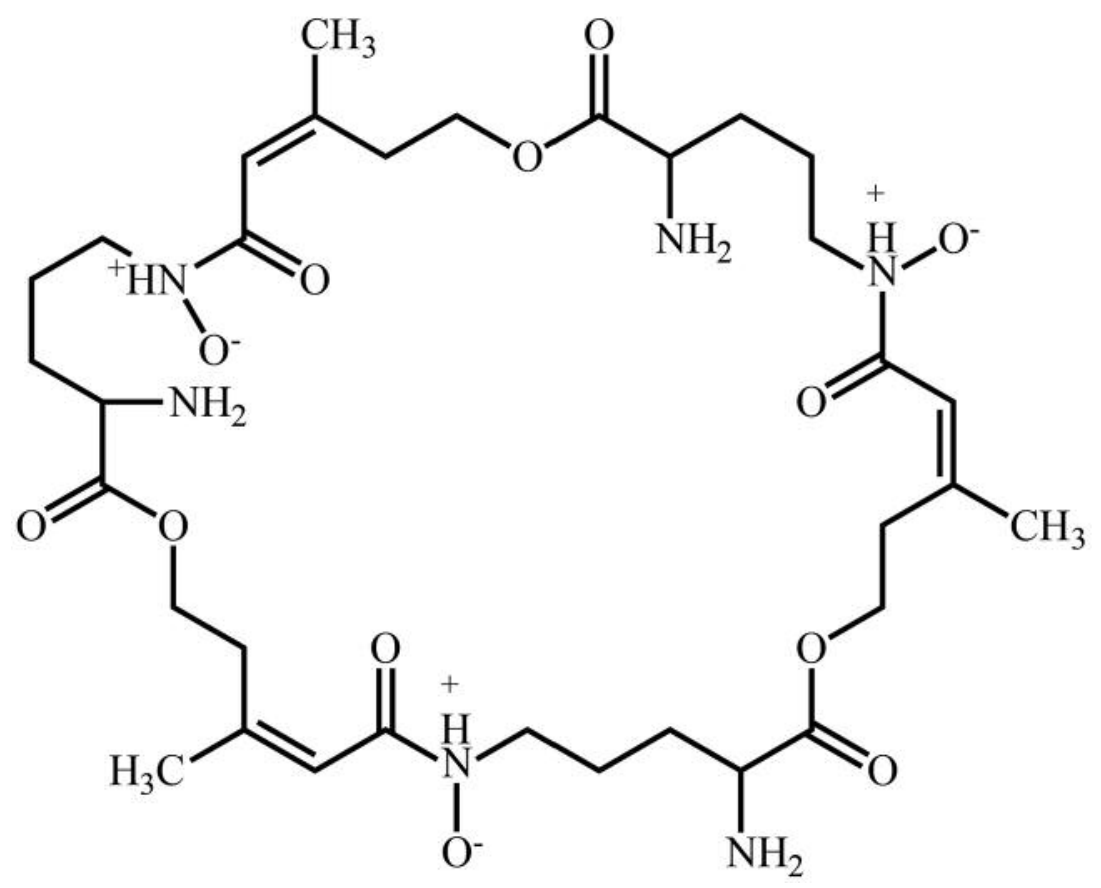

Figure 1. Structure of fusigen.

Darmstadt, Germany). Mean of fluorescence intensity was determined by Guava ${ }^{\circledR}$ InCyte software (Merck) analysis of the record histogram.

Nitric oxide detection. The intracellular NO was analyzed by flow cytometry using DAF-FM DA as a NO-specific fluorescent probe. Cells were trypsinized and then incubated with $10 \mu \mathrm{M}$ DAF-FM DA in serum free DMEM for $30 \mathrm{~min}$ at $4^{\circ} \mathrm{C}$, and subsequently at $37^{\circ} \mathrm{C}$ for $2 \mathrm{~h}$. After incubation, cells were trypsinized, washed, resuspended, and immediately measured for green fluorescence intensity by Guava ${ }^{\circledR}$ easyCyte flow cytometer (Merck, Darmstadt, Germany). Mean of fluorescence intensity was quantified by Guava ${ }^{\circledR}$ InCyte software (Merck) analysis of the record histogram.

Statistical analysis. Data were expressed as the means \pm SD or SE from three or more independent experiments. Statistical analysis was performed by ANOVA at a significance level of $p<0.05$.

\section{Results}

Fusigen production from A. melanogenum. After screening 69 isolates of A. melanogenum from the PBURU culture collection of siderophore production, only A. melanogenum VK02 isolate from greasy aluminum surface in Ratchaburi province of Thailand could produce a superior yield of siderophore. The best siderophore production conditions and the process that could enhance siderophore production is shown in "Materials and Methods" section and Figure 2. The siderophore fusigen (chemical structure shown in Figure 1) was purified by flowing through Zetadex LH-20 column and $\mathrm{C}_{18}$ reverse-phase column. The purified fusigen was analyzed by $\mathrm{C}_{18}$ reverse-phase HPLC as described in "Materials and Methods" section. The purity of the fusigen is shown by the HPLC analysis, which shows only one clear peak at retention time of $10.063 \mathrm{~min}$ (Figure 3).

Effect of fusigen on viability of cells. To determine toxicity of the purified fusigen (Figure 2), human normal epithelial BEAS and human DP cells were incubated with various concentrations of fusigen. After $24 \mathrm{~h}$, cell viability was determined by MTT assay. Figure 4 shows that fusigen caused no cytotoxicity to BEAS and DP cells at concentrations up to $100 \mu \mathrm{M}$. In order to test the possible effects of the compound on the levels of intracellular ROS and NO, fusigen was used at the concentrations of 0,50 , and $100 \mu \mathrm{M}$.

Fusigen inhibition of accumulated ROS generation. BEAS and DP cells were exposure to the DCFH-DA fluorescence dye for $30 \mathrm{~min}$ in the presence or absence of $50-100 \mu \mathrm{M}$ fusigen and intracellular ROS levels were then analyzed by flow cytometry after $1 \mathrm{~h}$. Figure 5 shows that the DCFH-DA fluorescent intensities in fusigen $(50$ and $100 \mu \mathrm{M})$ treated cells were significantly lower than those of control nontreated cells. In addition, fusigen showed strong anti-oxidant activity against high levels of oxidative stress induced by the treatment of BEAS cells with hydrogen peroxide $(100 \mu \mathrm{M})$ and $\mathrm{FeSO}_{4}(150 \mu \mathrm{M})$ plus hydrogen peroxide $(100 \mu \mathrm{M})$. The antioxidant effect of the compound was confirmed in the DP cells treated with hydrogen peroxide. 


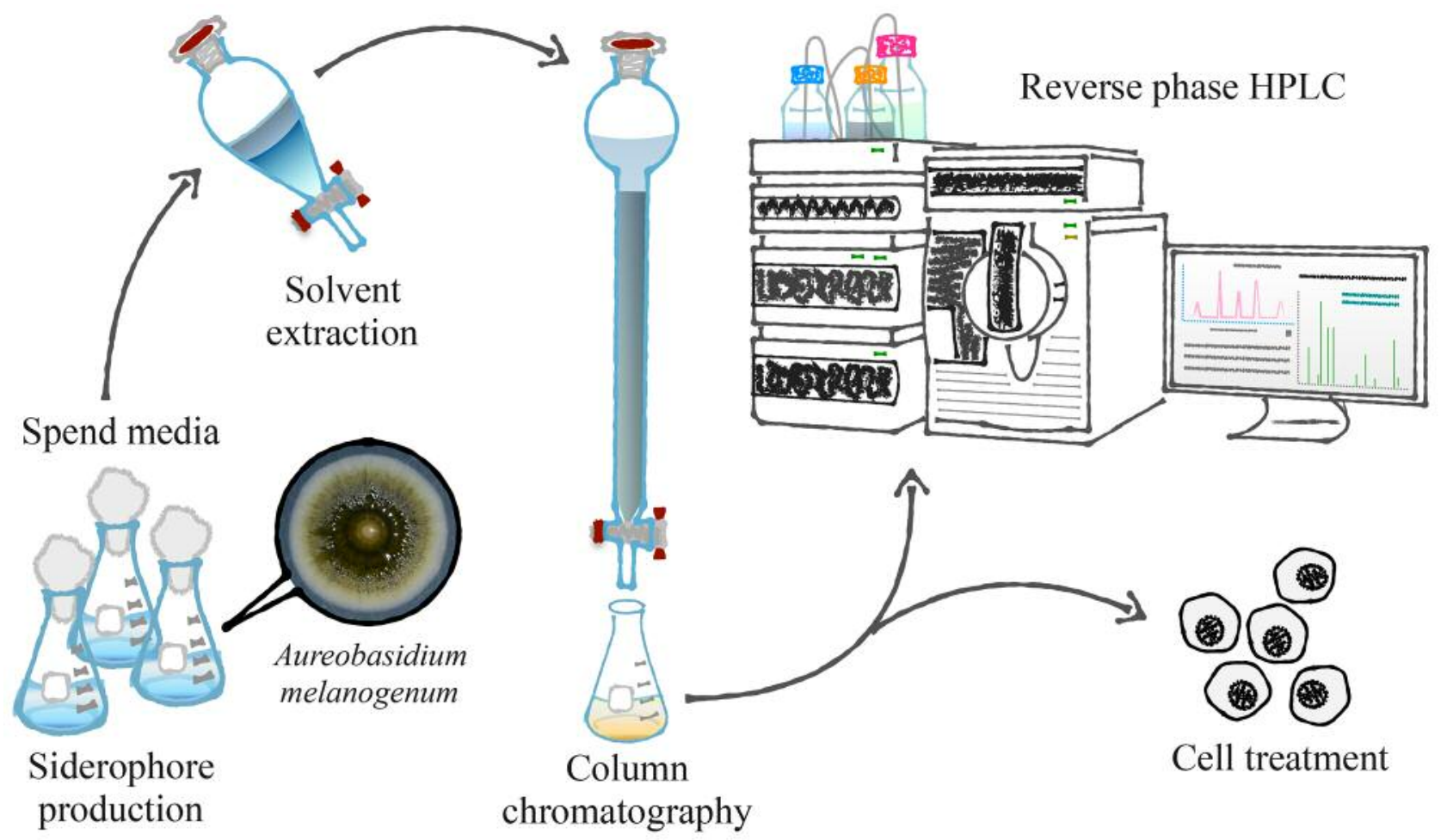

Figure 2. Overall scheme of fusigen production .

Effect of fusigen on NO levels. Like ROS, NO has been shown to contribute to several human pathologies. Therefore, the effect of fusigen on NO production in epithelial and DP cells was examined. Flow cytometric evaluation of intracellular NO levels was performed using DAF-FM DA as a NO specific probe. The cells were incubated with the fluorescence probe for $30 \mathrm{~min}$ and the intracellular NO level was determined after $2 \mathrm{~h}$. Figure 6 shows that the levels of NO in BEAS and DP cells were spontaneously up-regulated and the treatment of the cells with fusigen at the concentrations of 50 and $100 \mu \mathrm{M}$ attenuated the increase of NO.

\section{Discussion}

Oxidative stress and reactive nitrogen species have been recognized as important accelerators of human diseases. In particular, the oxygen-derived radicals like hydroxyl radical and others have been shown to cause DNA damage that may contribute to cancers $(24,25)$. In addition, neurodegenerative diseases as well as the inflammatory related diseases have been shown to be linked with excessive production of cellular ROS (26-28). They are involved in production and aggregation of A $\beta$ in Alzheimer's disease (29). Moreover, they play a role in Parkinson's disease by inducing apoptosis. In cancer, ROS play a role in DNA damage, initiation of tumorigenicity, and enhancement of invasion and metastasis (30-32). These studies have highlighted the importance of potent anti-oxidant compounds for the treatment or prevention of ROS-related diseases.

Here, we invented the process of fusigen production. The effect of culture medium on siderophore production from $A$. melanogenum VK02 was studied using various carbon sources including glucose, fructose, xylose, sucrose, and soluble starch, and nitrogen sources including $\left(\mathrm{NH}_{4}\right)_{2} \mathrm{SO}_{4}$, $\mathrm{NH}_{4} \mathrm{NO}_{3}, \mathrm{NaNO}_{3}, \mathrm{KNO}_{3}$, and urea. Various concentrations of L-glutamate, L-ornithine, and L-arginine were also used. The best conditions for siderophore production are found. Sucrose and $\left(\mathrm{NH}_{4}\right)_{2} \mathrm{SO}_{4}$ at $7 \%$ and $1.1 \%(\mathrm{w} / \mathrm{v})$, respectively, were found to be the best carbon and nitrogen sources for siderophore production. Three amino acids were selected as the precursors for siderophore biosynthetic pathway. Only Lornithine which is the key precursor of siderophore synthesis, enhanced siderophore production in this isolate. This carbon source and amino acid were also the best for siderophore production from A. melanogenum HN6.2 isolate (33). In contrast, the type of nitrogen source was different. A. melanogenum HN6.2 isolate preferred ammonium nitrate as a nitrogen source, while $\mathrm{VK} 02$ isolate preferred ammonium sulfate. The siderophore produced from $A$. melanogenum has been reported earlier to be fusigen, which 


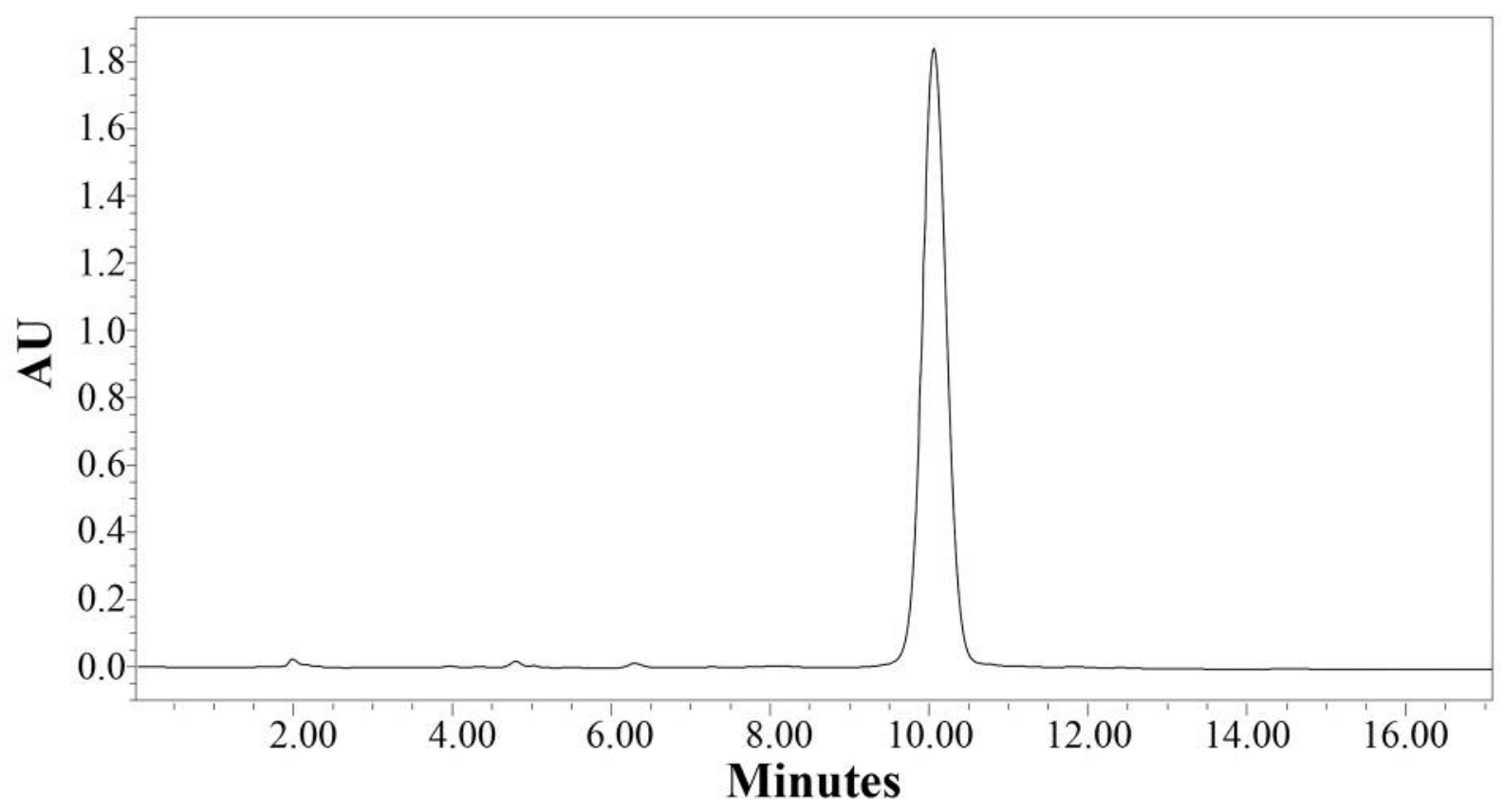

Figure 3. $C_{18}$ reverse-phase HPLC analysis of purified fusigen.
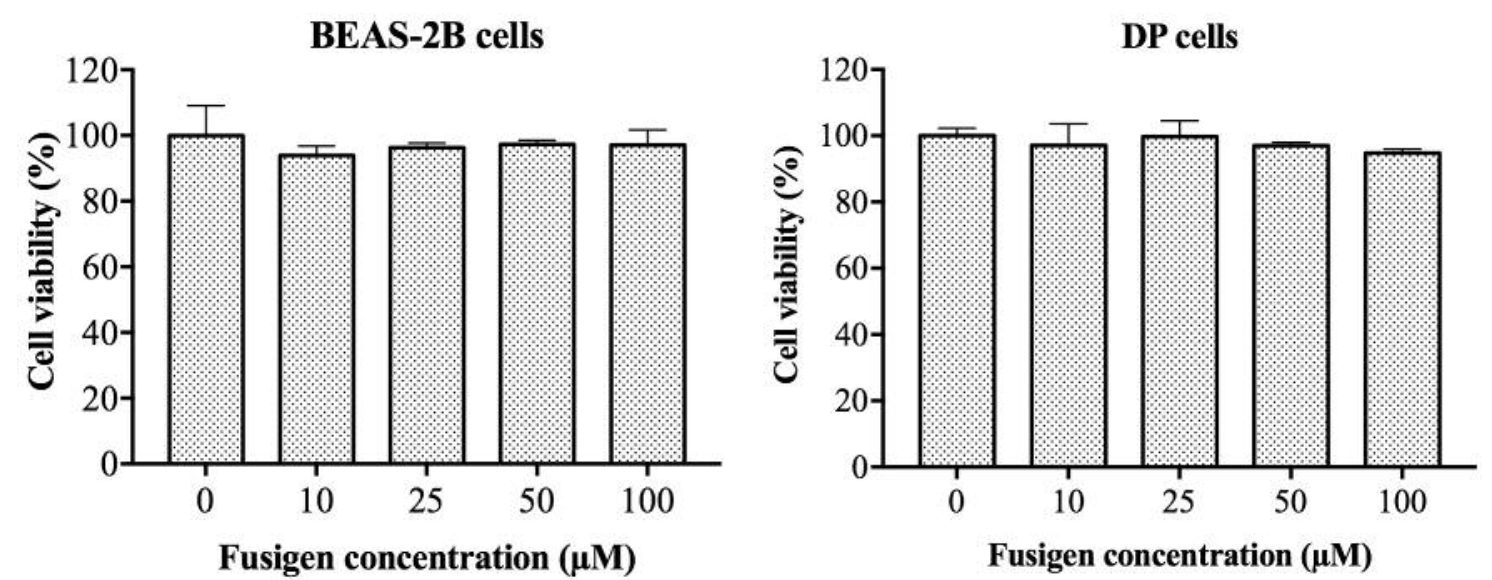

Figure 4. Percentage of cell survival in fusigen-treated human epithelial BEAS-2B and dermal papilla DP cells. Data are presented as the mean \pm SD $(n=4)$.

is one of the hydroxamate-type siderophores (23). Fusigen is also known as fusarinine C. Since the initial study on siderophores, it has been reported to be a stereotype from Fusarium species $(34,35)$. The purity of fusigen produced from VK02 isolate was determined by reverse-phase HPLC. A single sharp peak at $10.063 \mathrm{~min}$ of retention time was obtained, showing no contamination with other compounds.

Our results showed that fusigen was not toxic to human normal cells (Figure 4) at concentrations up to $100 \mu \mathrm{M}$. At the non-cytotoxic concentrations, fusigen could inhibit basal
ROS production and $\mathrm{H}_{2} \mathrm{O}_{2}$-induced ROS in BEAS and DP cells. Via Fenton reaction, hydrogen peroxide could be converted to highly reactive molecule hydroxyl radical. Hydroxyl radical is the most biologically active free radical formed under hypoxic conditions. Its formation could be promoted by iron and can be the cause of atherosclerosis (36, 37). Moreover, hydroxyl radical can induce polymerization of fibrinogen resulting in an insoluble fibrin-like precipitate. This precipitate is reported to be involved in some degenerative diseases such as atherosclerosis, cancer, and 

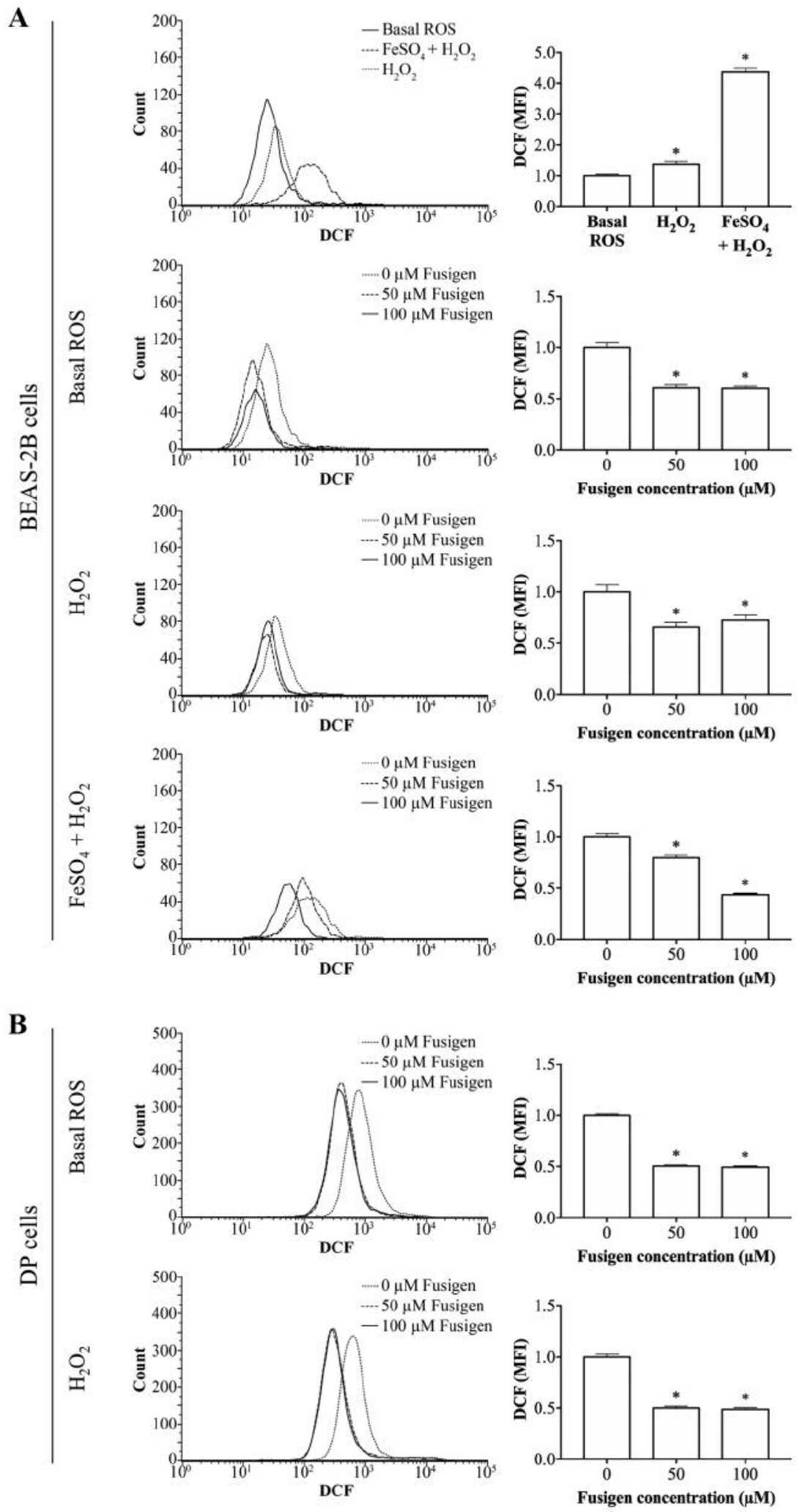

Figure 5. ROS scavenging activity of fusigen in BEAS-2B and DP cells. Cells were treated with $10 \mu M$ DCFH-DA and various concentrations of fusigen $(0,50$, and $100 \mu \mathrm{M})$ for $30 \mathrm{~min}$ at $4^{\circ} \mathrm{C}$ before treatment with ROS generators $\left(100 \mu \mathrm{M} \mathrm{H} \mathrm{H}_{2}\right.$ or $100 \mu \mathrm{M} \mathrm{H}_{2} \mathrm{O}_{2}+150 \mu \mathrm{M} \mathrm{FeSO}$ ) for 1 h. ROS production was determined by flow cytometry. Columns are means $\pm S E$ (count event $=5,000$ ). *Significantly different at $p<0.05$ compared to the untreated control group. 

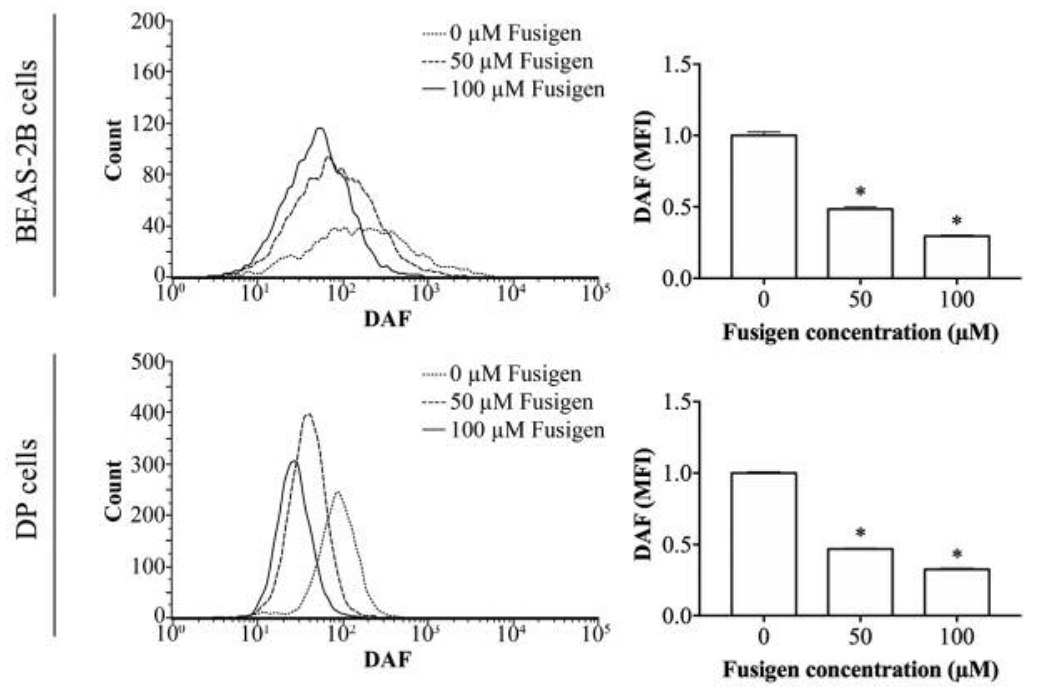

Figure 6. Effect of fusigen on NO levels in BEAS-2B and DP cells. Cells were treated with DAF-FM DA and various concentrations of fusigen (0, 50 , and $100 \mu \mathrm{M})$ for $30 \mathrm{~min}$ and NO levels were determined at $1 \mathrm{~h}$ by flow cytometry. Columns are means \pm SE (count event $=5,000)$. *Significantly different at $p<0.05$ compared to the untreated control group.

neurological disorders (38-41). The increase in cellular oxidative stress in the BEAS cells treated with hydroxyl radical generator could be attenuated by treating with fusigen, suggesting the use of this agent in the protection from harmful hydroxyl radicals. In addition, the NO suppressive effect of fusigen was also demonstrated (Figure 6). As NO may contribute to several human diseases including cancers and inflammation, this NO suppressive activity of fusigen may be useful for treating these conditions.

In conclusion, a novel process of fusigen production was presented as well as its activity in reducing cellular ROS and NO. Fusigen shows promising effects with low toxicity to normal cells. These findings support the use of fusigen in the treatment of oxidative stress-related diseases.

\section{Conflicts of Interest}

The Authors have no conflicts of interest to declare regarding this study.

\section{Authors' Contributions}

Conceptualization, P.C.; Methodology, V.K., S.P., and P.C. Investigation, V.K., P.L., C.K., P.P., H.P., S.P., and P.C. Writingoriginal draft preparation, V.K. and P.C.; Writing-review and editing, P.C.; Funding acquisition, P.C.; Supervision, S.P. and P.C.

\section{Acknowledgements}

This research was supported by the $90^{\text {th }}$ Anniversary of Chulalongkorn University, Rachadapisek Sompote Fund, and the Grant for International Research Integration: Research Pyramid,
Ratchadaphiseksomphot Endowment Fund (GCURP_58_01_33_01), Chulalongkorn University. The Authors acknowledge the instrument provided by Pharmaceutical Research Instrument Center, Faculty of Pharmaceutical Sciences, Chulalongkorn University.

\section{References}

1 Farber JL: Mechanisms of cell injury by activated oxygen species. Environ Health Perspect 102: 17-24, 1994. PMID: 7705293, DOI: 10.1289/ehp.94102s 1017

2 Halliwell B and Gutteridge JM: Free radicals in biology and medicine. Oxford University Press, 2015. DOI:10.1093/ acprof:oso/9780198717478.001.0001

3 AbouL-Enein AM, El-Baz FK, El-Baroty GS, Youssef A and Abd El-Baky HH: Antioxidant activity of algal extracts on lipid peroxidation. J Med Sci 3(1): 87-98, 2003. DOI: 10.3923/jms.2003.87.98

4 Halliwell B and Gutteridge JM: Role of free radicals and catalytic metal ions in human disease: An overview. Methods Enzymol 186: 1-85, 1990. PMID: 2172697, DOI: 10.1016/00766879(90)86093-B

5 Winterbourn CC: Toxicity of iron and hydrogen peroxide: The fenton reaction. Toxicol Lett 82-83: 969-974, 1995. PMID: 8597169, DOI: 10.1016/0378-4274(95)03532-X

6 Dizdaroglu M and Jaruga P: Mechanisms of free radical-induced damage to DNA. Free Radic Res 46(4): 382-419, 2012. PMID: 22276778, DOI: 10.3109/10715762.2011.653969

7 Vallance P and Charles I: Nitric oxide as an antimicrobial agent: Does no always mean no? Gut 42(3): 313-314, 1998. PMID: 9577329, DOI: $10.1136 /$ gut.42.3.313

8 Martinez-Ruiz A, Cadenas S and Lamas S: Nitric oxide signaling: Classical, less classical, and nonclassical mechanisms. Free Radic Biol Med 51(1): 17-29, 2011. PMID: 21549190, DOI: $10.1016 /$ j.freeradbiomed.2011.04.010 
9 Cauwels A: Nitric oxide in shock. Kidney Int 72(5): 557-565, 2007. PMID: 17538569, DOI: 10.1038/sj.ki.5002340

10 Lorente JA, Landin L, De Pablo R, Renes E and Liste D: Larginine pathway in the sepsis syndrome. Crit Care Med 21(9): 1287-1295, 1993. PMID: 8370291

11 Petros A, Lamb G, Leone A, Moncada S, Bennett D and Vallance P: Effects of a nitric oxide synthase inhibitor in humans with septic shock. Cardiovasc Res 28(1): 34-39, 1994. PMID: 7509259, DOI: $10.1093 / \mathrm{cvr} / 28.1 .34$

12 Pokidyshev DA, Bondarenko NA, Malyshev I, Mikoian VD, Kubrina LN, Vanin AF and Manukhina EB: [selective inhibition of inducible no-synthase by nonselective inhibitor]. Ross Fiziol Zh Im I M Sechenova 84(12): 1420-1427, 1998. PMID: 10204189

13 Neilands JB: Siderophores: Structure and function of microbial iron transport compounds. J Biol Chem 270(45): 26723-26726, 1995. DOI: $10.1074 /$ jbc.270.45.26723

14 Haas H: Fungal siderophore metabolism with a focus on Aspergillus fumigatus. Nat Prod Rep 31(10): 1266-1276, 2014 PMID: 25140791, DOI: 10.1039/c4np00071d

15 Adjimani JP and Asare P: Antioxidant and free radical scavenging activity of iron chelators. Toxicol Rep 2: 721-728, 2015. PMID: 28962407, DOI: 10.1016/j.toxrep.2015.04.005

16 Nagoba B and Vedpathak DV: Medical applications of siderophores. Eur J Gen Med 8(3): 229-235, 2011. DOI: 10.29333/ejgm/82743

17 Gostinčar C, Ohm RA, Kogej T, Sonjak S, Turk M, Zajc J, Zalar P, Grube M, Sun H and Han J: Genome sequencing of four Aureobasidium pullulans varieties: Biotechnological potential, stress tolerance, and description of new species. BMC Genomics 15(1): 549, 2014. PMID: 24984952, DOI: 10.1186/1471-2164-15-549

18 Lotrakul P, Deenarn P, Prasongsuk S and Punnapayak H: Isolation of Aureobasidium pullulans from bathroom surfaces and their antifungal activity against some Aspergilli. Afr $\mathrm{J}$ Microbiol Res 3(5): 253-257, 2009.

19 Prasongsuk S, Sullivan R, Kuhirun M, Eveleigh D and Punnapayak H: Thailand habitats as sources of pullulan-producing strains of Aureobasidium pullulans. World J Microbiol Biotechnol 21(4): 393-398, 2005. DOI: 10.1007/s11274-004-2237-x

20 Yanwisetpakdee B: Characterization of black yeast Aureobasidium spp. Isolated from thai coastal area, Chulalongkorn University, 2014.

21 Yanwisetpakdee B, Lotrakul P, Prasongsuk S, Seelanan T, White JF Jr, Eveleigh DE, Kim SW and Punnapayak H: Associations among halotolerance, osmotolerance and exopolysaccharide production of Aureobasidium melanogenum strains from habitats under salt stress. Pak J Bot 48(3): 1229-1239, 2016.

22 Prasongsuk S, Lotrakul P, Ali I, Bankeeree W and Punnapayak $\mathrm{H}$ : The current status of Aureobasidium pullulans in biotechnology. Folia Microbiol 63(2): 129-140, 2018. PMID: 29079936, DOI: 10.1007/s12223-017-0561-4

23 Wang W, Chi Z, Liu G, Buzdar MA, Chi Z and Gu Q: Chemical and biological characterization of siderophore produced by the marine-derived Aureobasidium pullulans HN6.2 and its antibacterial activity. Biometals 22(6): 965-972, 2009. PMID: 19459055, DOI: $10.1007 / \mathrm{s} 10534-009-9248-x$

24 Ames BN: Dietary carcinogens and anticarcinogens. Oxygen radicals and degenerative diseases. Science 221(4617): 12561264, 1983. PMID: 6351251, DOI: 10.1126/science.6351251

25 Waris $\mathrm{G}$ and Ahsan H: Reactive oxygen species: Role in the development of cancer and various chronic conditions. J Carcinog 5: 14-14, 2006. PMID: 16689993, DOI: 10.1186/14773163-5-14
26 Gandhi S and Abramov AY: Mechanism of oxidative stress in neurodegeneration. Oxid Med Cell Longev 2012: 428010, 2012. PMID: 22685618, DOI: 10.1155/2012/428010

$27 \mathrm{Kim}$ GH, Kim JE, Rhie SJ and Yoon S: The role of oxidative stress in neurodegenerative diseases. Exp Neurobiol 24(4): 325340, 2015. PMID: 26713080, DOI: 10.5607/en.2015.24.4.325

28 Patten DA, Germain M, Kelly MA and Slack RS: Reactive oxygen species: Stuck in the middle of neurodegeneration. J Alzheimers Dis 20: S357-367, 2010. PMID: 20421690, DOI: 10.3233/JAD-2010-100498

29 Zhao Y and Zhao B: Oxidative stress and the pathogenesis of alzheimer's disease. Oxid Med Cell Longev 2013: 316523, 2013. PMID: 23983897, DOI: 10.1155/2013/316523

30 Kundu N, Zhang S and Fulton AM: Sublethal oxidative stress inhibits tumor cell adhesion and enhances experimental metastasis of murine mammary carcinoma. Clin Exp Metastasis 13(1): 16-22, 1995. PMID: 7820952, DOI: 10.1007/BF00144014

31 North S, Moenner M and Bikfalvi A: Recent developments in the regulation of the angiogenic switch by cellular stress factors in tumors. Cancer Lett 218(1): 1-14, 2005. PMID: 15639335 , DOI: $10.1016 /$ j.canlet.2004.08.007

32 Reuter S, Gupta SC, Chaturvedi MM and Aggarwal BB: Oxidative stress, inflammation, and cancer: How are they linked? Free Radic Biol Med 49(11): 1603-1616, 2010. PMID: 20840865, DOI: 10.1016/j.freeradbiomed.2010.09.006

33 Wang W, Chi Z, Chi Z, Li J and Wang X: Siderophore production by the marine-derived Aureobasidium pullulans and its antimicrobial activity. Bioresour Technol 100(9): 2639-2641, 2009. PMID: 19162476, DOI: 10.1016/j.biortech.2008.12.010

34 Diekmann $\mathrm{H}$ and Zähner H: Konstitution von fusigen und dessen abbau zu $\delta 2$-anhydromevalonsäurelacton. Eur J Biochem 3(2): 213-218, 1967. DOI: 10.1111/j.1432-1033.1967.tb19518.x

35 Hider RC and Kong X: Chemistry and biology of siderophores. Nat Prod Rep 27(5): 637-657, 2010. PMID: 20376388, DOI: $10.1039 / \mathrm{b} 906679 \mathrm{a}$

36 Reis KA, Guz G, Ozdemir H, Erten Y, Atalay V, Bicik Z, Ozkurt $\mathrm{ZN}$, Bali $\mathrm{M}$ and Sindel S: Intravenous iron therapy as a possible risk factor for atherosclerosis in end-stage renal disease. Int Heart J 46(2): 255-264, 2005. PMID: 15876809, DOI: 10.1536/ihj.46.255

37 Sengoelge G, Sunder-Plassmann G and Hörl WH: Potential risk for infection and atherosclerosis due to iron therapy. J Ren Nutr 15(1): 105-110, 2005. PMID: 15648017, DOI: 10.1053/ j.jrn.2004.09.018

38 Costantini V, Zacharski LR, Memoli VA, Kisiel W, Kudryk BJ and Rousseau SM: Fibrinogen deposition without thrombin generation in primary human breast cancer tissue. Cancer Res 51(1): 349-353, 1991. PMID: 1670992

39 Duguid J: Thrombosis as a factor in the pathogenesis of coronary atherosclerosis. J Pathol Bacteriol 58(2): 207-212, 1946. PMID: 20996420, DOI: 10.1002/path.1700580207

40 Lipinski B: Hydroxyl radical and its scavengers in health and disease. Oxid Med Cell Longev 2011, 2011. PMID: 21904647 , DOI: $10.1155 / 2011 / 809696$

41 Smith EB: Fibrin deposition and fibrin degradation products in atherosclerotic plaques. Thromb Res 75(3): 329-335, 1994. PMID: 7992244, DOI: 10.1016/0049-3848(94)90246-1

Received December 26, 2018

Revised January 15, 2019

Accepted January 16, 2019 